PRZEGLĄDY - POLEMIKI - MATERIAEY

Kwartalnik Historyczny Rocznik CXXIV, 2017, 2

PL ISSN 0023-5903

\author{
RAFAE JAWORSKI \\ Uniwersytet Jana Kochanowskiego w Kielcach \\ Filia $w$ Piotrkowie Trybunalskim
}

\title{
SPIS POSŁÓW KORONNYCH NA SEJM KORONACYJNY W 1574 ROKU*
}

\begin{abstract}
Abstrakt: Przedmiotem artykułu jest ustalenie listy posłów koronnych izby poselskiej uczestniczących w sejmie koronacyjnym Henryka Walezego, pierwszego wybranego w wolnej elekcji króla Polski (Kraków, 21 lutego - 3 kwietnia 1574 r.). Zestawienie zostało oparte na dwóch źródłach dotychczas nieznanych: spisie posłów przygotowanym na potrzeby wypłaty zryczałtowanego wynagrodzenia za uczestnictwo w pracach parlamentu (pieniądze strawne) oraz rejestru pokwitowań odbioru powyższego wynagrodzenia.

Słowa kluczowe: życie polityczne, szlachta, Sejm, posłowie.
\end{abstract}

Abstract: The purpose of the article is to establish a register of envoys elected by sejmiki in the Polish Crown to the lower chamber of parliament, participating in the coronation Sejm of Henry Valois, the first king of Poland elected by free election (Kraków, 21 February to 3 April 1574). The register is based on two, unknown so far, source texts: a list of envoys written down for the purpose of paying out a flat-rate fee for participation in parliamentary works (the so-called strawne) and a register of receipts of the fee.

Keywords: political life, nobility, members of Parliament (envoys to the Sejm).

W badaniach nad przebiegiem poszczególnych sejmów doby staropolskiej ważne jest możliwie precyzyjne ustalenie listy uczestniczących w pracach parlamentu, zarówno zasiadających w senacie, jak i wybranych do izby poselskiej. Kluczową rolę w zestawianiu spisów posłów ziemskich odgrywają rejestry wypłaty strawnego. Były to imienne wykazy posłów, zapewne najczęściej przygotowywane przez marszałka izby poselskiej, a następnie przekazywane podskarbiemu nadwornemu czy

* Dziękuję Edwardowi Opalińskiemu za cenne uwagi na kolejnych etapach pracy nad poniższym artykułem. 
też koronnemu. Na ich podstawie ten ostatni dokonywał wypłaty pieniędzy strawnych, czyli zryczałtowanego wynagrodzenia za uczestnictwo w pracach parlamentu. Wykazy wypłat wciągano następnie do ksiąg tzw. rachunków sejmowych lub rachunków królewskich¹.

Dotychczas dysponowaliśmy spisami strawnego dla kilkunastu szesnastowiecznych sejmów ${ }^{2}$. Statystykę tę poprawia niedawno zidentyfikowany spis posłów koronnych posłujących na sejm koronacyjny $1574 \mathrm{r}$. Odprawiony w Krakowie od 21 lutego do 22 kwietnia $1574 \mathrm{r}^{3}$ sejm był

${ }^{1}$ Na temat instytucji pieniędzy strawnych zob. W. Uruszczak, Sejm walny koronny w latach 1506-1540, Warszawa 1980, s. 52-55 (III.3: Strawne); I. Kaniewska, „Strawne pieniądze" posłów koronnych w XVI wieku, w: Poprzez stulecia. Księga pamiatkowa ofiarowana profesorowi Antoniemu Podrazie w 80. rocznice Jego urodzin, red. D. Czerska, Kraków 2000, s. 57-66; A. Filipczak-Kocur, Kto wypłacat diety poselskie w XVII wieku?, w: Parlament, prawo, ludzie. Studia ofiarowane profesorowi Juliuszowi Bardachowi w sześćdziesięciolecie pracy twórczej, red. K. Iwanicka, M. Skowronek, K. Stembrowicz, Warszawa 1996, s. 68-73. O ile powyższe artykuły konstruują naszą wiedzę na temat podstaw prawnych wypłaty strawnego oraz ich roli w relacjach między izbą poselską a monarchą w XVI i XVII w., to niewiele wnoszą co do technicznej strony organizacji wypłaty.

${ }^{2}$ Jedenaście z nich uwzględniła w swoim zestawieniu A. Filipczak-Kocur (op. cit., tabl. III: „Wykaz wypłaconych diet poselskich”): AGAD, Archiwum Skarbu Koronnego (dalej: ASK), Oddz. II, Rachunki sejmowe, sygn. 20 (sejm 1553 r.), 22 (1562/63; 1563/64), 23 (1564; 1565; 1566; 1567), 27 (1578), 32 (1585), 33 (1589) oraz BN, Biblioteka Ordynacji Zamoyskich, sygn. 1171 (1597). Tę liczbę możemy uzupełnić o nieuwzględnione w zestawieniu spisy strawnego z sejmów z lat 1507, 1510, 1511, 1512 (dwa spisy), pochodzące z AGAD, ASK, Oddz. I, Rachunki królewskie, sygn. 38 (M. Lubczyński, Wykazy posłów sejmowych z lat 1507-1512, KH 122, 2015, 3, s. 509-537) oraz z sejmów z 1576 r.: koronacyjnego i toruńskiego (AGAD, ASK, Oddz. I, Rachunki królewskie, sygn. 251). Informację o nich podał Marek Ferenc (Rejestr wypłat strawnego dla posłów ziemskich koronnych na sejm warszawski 1582 r., SH 51, 2008, 1 (201), s. 91, przyp. 2). Częściowo brak spisów strawnego pozwalają zastąpić informacje o nazwiskach posłów delegowanych na sejmy pochodzące z dokumentacji sejmikowej oraz źródeł nieurzędowych, przede wszystkim diariuszów sejmowych. Przykładem nieurzędowego spisu posłów może być sporządzony przez niezidentyfikowanego bliżej „Przesmyckiego” rejestr senatorów i posłów sejmu warszawskiego 1600 r. (wyd. A. Radaman, M. Ferenc, Rejestr senatorów i posłów na sejmie walnym warszawskim 9 lutego - 21 marca 1600 r., „Zeszyty Naukowe Uniwersytetu Jagiellońskiego ” 767, Prace Historyczne 131, 2004, s. 89-107).

${ }^{3}$ W literaturze przedmiotu nie ma porozumienia co do terminu zakończenia obrad sejmu. O ile panuje zgoda co do daty jego rozpoczęcia (21 II 1574), to w opracowaniach pojawiają się cztery warianty daty zamknięcia: - 2 kwietnia (W. Konopczyński, Chronologia sejmów polskich 1493-1793, Kraków 1948, s. 141, poz. 78); - 3 kwietnia (tę datę przyjęli wydawcy spisu posłów [Posłowie ziemscy koronni 1493-1600, red. I. Kaniewska, Warszawa 2013 (dalej: PZK), s. 218], najprawdopodobniej idąc za sugestią Ewy Dubas-Urwanowicz [Koronne zjazdy szlacheckie $w$ dwóch pierwszych bezkrólewiach po śmierci Zygmunta Augusta, Białystok 1998, s. 307] że tego dnia Kraków opuściła większość izby poselskiej); - 22 kwietnia (tak w tytule szóstego rozdziału pracy Dubas-Urwanowicz („,Sejmy 
pierwszym, na którym stan sejmujący stanowił król wybrany w wolnej elekcji. Nie brakowało również na nim dyskusji na temat przyszłości ustroju Rzeczypospolitej (m.in. o charakterze konfederacji warszawskiej, formie i znaczeniu pacta conventa i artykułów henrykowskich). Cieniem na nim położyła się śmierć Andrzeja Wapowskiego, kasztelana przemyskiego, z ręki Samuela Zborowskiego ${ }^{4}$.

Jak pisze Ewa Dubas-Urwanowicz, „sejmiki ziemskie przysłały zwyczajową liczbę posłów, wybranych na wrześniowych sejmikach ziemskich. Sejm ten więc obradował prawdopodobnie w nieomal pełnym składzie"5. Listę posłów koronnych na pierwszym i, jak się okazało, jedynym sejmie za panowania Henryka Walezego, dotychczas rekonstruowano na podstawie dzieła Świętosława Orzelskiego ${ }^{6}$, a także nielicznych zachowanych akt sejmikowych oraz dokumentów wystawionych podczas sejmu. Źródła te pozwoliły Markowi Ferencowi na ustalenie 43 nazwisk członków izby poselskiej ${ }^{7}$. Dzięki dwóm, jak się wydaje dotychczas niewykorzystanym przez badaczy, świadectwom, jesteśmy w stanie ustalić listę posłów ziemskich koronnych na ten sejm.

koronacyjne. Sejm koronacyjny Henryka Walezego (21 lutego 1574 r. - [3] 22 kwietnia 1574 r.", s. 307). Autorka opierała się tu na datacji potwierdzenia praw wystawionego przez nowego króla: „[--] Dan w Krakowie, 22 Aprilis na sejmie koronacyi Naszej, roku Bożego MDLXXIV [--]" (VC 2/1, s. 334), co sugerowałoby, że sejm jeszcze 22 kwietnia obradował; - 23 kwietnia (M. Serwański, Henryk Walezy w Polsce. Stosunki polsko-francuskie w latach 1566-1576, Kraków 1976, s. 181). E. Dubas-Urwanowicz, omawiając ten problem przyjęła, że 3 kwietnia zakończyła obrady izba poselska, natomiast senat pracował do 22 kwietnia (op. cit., s. 314-315). Idąc za powyższymi ustaleniami, przyjmuję że sejm zakończył się 22 kwietnia $1574 \mathrm{r}$.

${ }^{4}$ Sejm ten, podobnie zresztą jak zdecydowana większość sejmów z XVI w., nie doczekał się własnej monografii. Jak zauważył Jan Seredyka (Parlamentarzyści polscy od końca XV wieku do 1632 r., w: Parlamentarzyści polscy od XVI do XX wieku. Stan badań i postulaty, red. J. Seredyka, Opole 1999, s. 14), „literatura prezentuje go zaledwie epizodycznie”. Obrady sejmu koronacyjnego znalazły się na marginesie prac Stanisława Grzybowskiego (Henryk Walezy, wyd. 2, Wrocław 1985) i Macieja Serwańskiego (op. cit.). Sytuację tę poprawiła publikacja pracy Ewy Dubas-Urwanowicz (zob. przyp. 3), gdzie przebieg obrad oraz jego problematykę omówiono w rozdziale szóstym (ibidem, s. 307-324). O zabójstwie Wapowskiego zob. D. Makiłła, Zabójstwo Andrzeja Wapowskiego, kasztelana przemyskiego, przez Samuela Zborowskiego na sejmie koronacyjnym króla Henryka Walezego w 1574 r. Z zasad stosowania spraw postepku sadowego w sprawach karnych $w$ dawnej Polsce, $\mathrm{w}$ : Historia testis temporum, lux veritatis, vita memoriae, nuntia vetustatis. Ksiega Jubileuszowa dedykowana Profesorowi Włodzimierzowi Kaczorowskiemu, red. E. Kozierska, M. Maciejewski, P. Stec, Opole 2015, s. 237-253.

${ }^{5}$ E. Dubas-Urwanowicz, op. cit., s. 307.

6 Świętosława Orzelskiego Bezkrólewia ksiąg ośmioro 1572-1576, wyd. E. Kuntze, Kraków 1917 („Scriptores rerum Polonicarum”, t. 22) (dalej: Orzelski).

7 Sejm koronacyjny w Krakowie 21 II do 3 IV 1574 r., oprac. M. Ferenc, w: PZK, s. 218-224. 
Podstawowy do przeprowadzenia rekonstrukcji jest wspomniany wyżej, przechowywany w zbiorach Muzeum Narodowego w Krakowie (obecnie w Bibliotece Czartoryskich), wśród materiałów kolekcji Wiktora W. Wittiga, rejestr (dalej będziemy nazywać go Spisem Krakowskim [SK]). Pisarz opatrzył sporządzony przez siebie rejestr łacińskim tytułem: "Nuncii terrestres Regni Poloniae in Conventu Coronationis Anno 1574".

Na kolejnych kartach wymieniono 113 posłów, zgodnie $\mathrm{z}$ formularzem znanym ze spisów strawnego, a więc podzielonych według województw i ziem oraz (w przypadku województw mazowieckiego, podlaskiego, rawskiego i bracławskiego) również powiatów, z których zostali wybrani. Nazwy jednostek administracyjnych zapisano po łacinie i wyróżniono pogrubieniem. Zachowano przy tym przybliżoną kolejność województw i ziem zgodną z Porządkiem Rady Koronney, Polskiey y Litewskiey, iako iuż iedney Rzpltey ustalonym na sejmie lubelskim 1569 r. W przypadku większości posłów zanotowano ich imiona (w formie łacińskiej lub zlatynizowanej), nazwiska oraz zajmowany urząd (również po łacinie). Kilkunastu posłów określono jedynie z imienia i nazwiska lub jedynie nazwiska. Są również posłowie, których pisarz zanotował wyłącznie z piastowanego urzędu. Starał się w obrębie poszczególnych pozycji (województw, ziem i powiatów) zachować hierarchię urzędniczą. W przypadku trzech posłów (Stanisława Górki, Jerzego Latalskiego oraz księcia Konstantego Ostrogskiego) pisarz poprzedził ich nazwiska literą M., najprawdopodobniej jako skrót od Magnificus. Nie przypadkiem wyróżniono i uhonorowano w ten sposób posłujących wojewodziców, niepiastujących w tym czasie żadnego urzędu.

SK pod względem formularza, sposobu zapisu odnotowania posłów, nie odbiega zatem od zidentyfikowanych rejestrów strawnego. Różni go jednak brak wskazania sum wypłaconych ze skarbca oraz końcowego zliczenia całości wydatków poniesionych przez skarb królewski z tytułu wypłaty strawnego. Można więc założyć, że omawiany dokument nie pochodzi z jednej z ksiąg rachunków sejmowych. Najprawdopodobniej SK został przygotowany na polecenie marszałka izby poselskiej Wacława (Wencława) Agryppy. Dziwić może jednakże fakt, że spis nie nosi żadnego śladu uwierzytelnienia ze strony marszałka izby (podpisu i pieczęci). Zaskakuje również wspomniana wyżej niekompletność podanych danych oraz pojawiające się błędy (przede wszystkim w imionach). Wydawałoby

${ }^{8}$ BCz, Zbiory Muzeum Narodowego w Krakowie, sygn. 522/2. Dwie karty papieru, formatu pagina fracta, zszyta składka (binio), zapisana pismem jednej ręki. Na papierowej obwolucie: „Agrippa Wacław, sekretarz króla, a na ten czas marszałek poselski w r. 1574 z kartką do pan Młodziejowskiego. Spis posłów ziemskich Królestwa Polskiego na koronację krakowską w 1574 r.” (długopisem, XX w.). Na odwrocie: „Z daru W. W. Wittiga” (pieczątka w tuszu niebieskim, XIX w.); „N.J. 44373” (ołówkiem, XX w.). 
się, że w tego rodzaju dokumencie dane poszczególnych członków izby poselskiej winny być pełne, a więc wszyscy posłowie winni być opisani z imienia i nazwiska oraz urzędu (o ile taki posiadali). Tak jednak się nie stało. Również w przypadku innych zachowanych spisów wypłaty strawnego część posłów odnotowano jedynie z nazwiska i/lub posiadanego urzędu. W tym kontekście pojawia się pytanie, na jakiej podstawie sporządzano spisy (zarówno ten z sejmu koronacyjnego 1574 r., jak też pozostałe). Gdyby była nią dokumentacja sejmikowa, to dane z pewnością byłyby dokładniejsze .

Interpretację charakteru spisu pozwala wyjaśnić dołączona do niego, a precyzyjniej: wszyta, ćwiartka arkusza papieru. Dokument ten to krótki odręczny list marszałka izby poselskiej Wacława Agryppy ${ }^{10}$ skierowany do pisarza skarbowego Jacka Młodziejowskiego ${ }^{11}$. Przytaczamy go w całości: „M(iłościwy) Moy Łaskawy Panie Mlodzyeowsky w(aszej) m(iłości) ozna|muję yz pan Se(basti)an Pysarzowsky podsendek za|torsky jest poslem woyewoczkym cracowskym a s powyatu Zatorskiego. O czym wssymy wy|adomo czniamy. Dan w zamku cracowskym | dzys ut supra |w(aszej) miłości | na wszem powolny | Wacław Agrippa Sekretarz Krolia | Jego Miłości, a na ten czas Marschalek | Poselski wlasną ręką s(up)s(cripsi)t”.

Znamienne, że nazwiska Pisarzowskiego nie znajdujemy w SK. Zwraca też uwagę datacja listu, ograniczona zaledwie do formuły: „Dan w zamku cracowskym dzys ut supra". Pozwala ona założyć, że tego (bliżej niestety nieokreślonego) dnia marszałek izby poselskiej wymieniał już korespondencję z pisarzem. $Z$ dużą dozą prawdopodobieństwa można przyjąć, że był to przekazany na ręce Młodziejowskiego spis posłów, którym należy się strawne. Zapewne po jego ekspedycji zauważono pominięcie jednego z posłów. List Agrypy byłby więc aneksem do przekazanego już pisarzowi spisu, który jeszcze tego samego dnia przesłano pisarzowi. Możliwe również, że błąd zauważono jeszcze zanim spis wysłano do

9 Trudności interpretacyjne budzi również umieszczona na końcu spisu zapiska sporządzona tą samą ręką co cały spis: „Z Lythewskiego Kxyeshwa wpisą thu pissarz”. Trudno o jego jednoznaczną interpretację. Być może piszący w ten sposób zaznaczył, że posłów z Litwy wpisze inny pisarz?

${ }_{10}$ Wacław (Wencław) Agryppa h. Dębno (zm. 1597), sekretarz królewski 1569, pis. wlki lit. 1576, klan miński 1586, klan smoleński 1590, marsz. izby poselskiej sejmu koronacyjnego 1574 r. (K. Tyszkowski, Agryppa Wacław, PSB, t. 1, Kraków 1935, s. 32-33; Urzędnicy, t. 11, s. 198; A. Rachuba, Litewscy marszałkowie sejmów Rzeczypospolitej (15691793), w: Kultura parlamentarna epoki staropolskiej. Studia, red. A. Stroynowski, Warszawa 2013, s. 37).

${ }^{11}$ Jacek Młodziejowski h. Ślepowron (?; zm. 1604), pisarz skarbowy 1572-1580, podskarbi nadworny 1580-1604, żupnik krakowski 1592-1595 (Urzędnicy, t. 10, s. 186; H. Kowalska, Młodziejowski Jacek, PSB, t. 21, Wrocław 1976, s. 433-434). 
adresata. Zdecydowano wówczas, by już nie przepisywać gotowego czystopisu spisu, a jedynie go aneksować w formie dołączonego do niego listu marszałka izby. W takim przypadku do Młodziejowskiego trafił jednocześnie spis wraz z listem-aneksem.

Niestety brak zachowanej dokumentacji związanej z organizacją wypłat strawnego nie pozwala stwierdzić, czy stałą praktyką było przekazywanie przez marszałka spisu posłów na ręce pisarza skarbowego ${ }^{12}$, czy też Jacek Młodziejowski występował tu in absentia podskarbiego nadwornego koronnego. Wakujące od śmierci Jana Lutomirskiego (zm. 11 IX 1567) podskarbiostwo objął Jakub Rokossowski. Po raz pierwszy z tym urzędem jest wzmiankowany 25 maja 1574 r., a więc niewiele ponad miesiąc po zakończeniu obrad sejmu koronacyjnego ${ }^{13}$. Nie możemy zatem wykluczyć zarówno sytuacji, że w momencie przygotowania spisu (czyli najprawdopodobniej w końcu marca lub na początku kwietnia 1574 r.) podskarbiostwo nadworne wakowało, jak też że zostało przez nowego króla już obsadzone. Oba rozstrzygnięcia są równie prawdopodobne.

Fakt, że w przypadku listu zachowano praktycznie pełny formularz przewidziany dla korespondencji ${ }^{14}$, wyklucza raczej możliwość, iż spis przekazano do skarbu nadwornego w formie będącej podstawą niniejszej edycji. Raczej mamy tu do czynienia z roboczą wersją (brudnopisem), która stała się podstawą do sporządzenia niezachowanego czystopisu (możliwe, że już bez błędów, z kompletnymi danymi posłów), i na jej podstawie dokonano wypłat strawnego oraz sporządzono (również niezrachowany) wpis do ksiąg sejmowych.

Odrębną kwestią pozostaje wyjaśnienie, w jakich okolicznościach zszyto brudnopis spisu z listem. Wydaje się, że bardziej logiczne było trwałe połączenie listu z czystopisem wykazu. Możliwe, że w niedających się bliżej poznać okolicznościach do akt podskarbińskich trafił brudnopis spisu, z czasem połączony z listem.

Inny charakter ma drugie z wykorzystanych źródeł, który dalej określać będziemy jako Spis Warszawski (SW). To składka z siedmiu kart (dutek), wszyta do oprawionego poszytu różnych rachunków z lat 15351574 wchodzącego w skład działu Rachunków Królewskich Archiwum

12 W tym przypadku może akceptowane było dostarczanie pisarzowi skarbowemu spisu posłów w formie brudnopisu i na jego podstawie już w kancelarii podskarbiego przygotowywano czystopis.

${ }^{13}$ Data za: Urzędnicy, t. 10, s. 129, nr 784. Z kolei H. Kowalska (Rokossowski Jakub, PSB, t. 31, Wrocław 1988, s. 537) podaje, że „mianowany podskarbim nadwornym, wziął $21 \mathrm{~V} 1574$ za 10800 złp. na trzy lata w dzierżawę star. krzepickie od miecznika kor. Mikołaja Wolskiego".

${ }^{14}$ Brakuje jedynie odcisku pieczęci nadawcy (wystawcy). 
Skarbu Koronnego ${ }^{15}$. Nieznany pisarz zatytułował go „Expeditio nuntiorum terrestrium in Conventione quails felicis Coronationis SMR". Nad nagłówkiem ręką z epoki dopisano: „Anno Domini 1574”. Już w XIX w. dopisano: „Wyd(atki) król(ewskie) na Posłów Koronnych na Sejm Koronacyjny zgromadzonych". Tą samą ręką co tytuł na kolejnych kartach wpisano po łacinie nazwy województw (przy niektórych oddając podział na powiaty/ziemie), pozostawiając jednocześnie między kolejnymi wpisami wolne miejsce (najczęściej po pół karty). Tak przygotowany formularz został wykorzystany do kwitowania przez posłów odbioru pieniędzy strawnych. Pokwitowania wpisywali osobiście lub (zaledwie trzech przypadkach) pieniądze odbierali w ich imieniu słudzy lub inni posłowie. Zwraca również uwagę różnorodność języka, w jakim dokonywano poświadczenia. Posłowie podpisywali się zarówno po polsku ${ }^{16}$, jak i po łacinie $^{17}$, a nawet mieszaniną obu języków ${ }^{18}$. Kilku posłów z województwa kijowskiego wpisało się alfabetem cyrylickim ${ }^{19}$. W SW znajdujemy nazwiska 79 posłów na sejm koronacyjny. Wszystkie pokrywają się z SK.

Z SW można wywnioskować, że ustalono trzy stawki strawnego w wysokości 30, 48 i 80 zł. Odbiór niższej stawki pokwitowali dwaj posłowie z województwa rawskiego. Najwyższą kwotę 80 zł tytułem strawnego odebrał posłujący z województwa poznańskiego Stanisław Sędziwój Czarnkowski. W pozostałych przypadkach kwitowano odbiór 48 zł. Możemy na podstawie tych szczątkowych danych przyjąć, że stawki te nie odbiegały od zwyczajowych, znanych z poprzednich sejmów. Tak więc posłowie z poznańskiego i kaliskiego otrzymali po 80 zł, natomiast posłowie $\mathrm{z}$ województw: mazowieckiego, płockiego, rawskiego, brzeskiego i inowrocławskiego - 30 zł. Pozostałym posłującym wypłacono po $48 \mathrm{zł}^{20}$.

SW pozwala zweryfikować ustalenia oparte o SK. W kilku przypadkach, gdy w SK o posłującym podano dane ograniczone (np. jedynie nazwisko) lub wręcz błędne, informacje z SW pozwoliły rozpoznać posła lub rozstrzygnąć wątpliwości co do identyfikacji.

${ }^{15}$ AGAD, ASK, Oddz. I, Rachunki królewskie, sygn. 361, k. 276-282v. Źródło to odnalazł i zidentyfikował Mariusz Lubczyński (Biblioteka Uniwersytecka UJK w Kielcach). Pragnę w tym miejscu bardzo podziękować za podzielenie się ze mną tym cennym znaleziskiem i zgodę na jego wykorzystanie w niniejszym artykule.

${ }^{16}$ Np.: „Stanisław Zolkiewski własną ręką” (SW, k. 277).

17 Np.: „Andreas Firley capita(neus) Sendo(miriensis) s(ub)s(cripsi)t” (SW, k. 276).

${ }^{18}$ Np.: „Adam Goraijski z Goraia ręką wlassną s(ub)s(cripsi)t” (SW, k. 276v).

${ }^{19}$ Np.: „Ivan Syšanskji vzâl zolotyh sorok osm” (SW, k. 282).

${ }^{20}$ Podobne stawki (odpowiednio 80, 48 i 32 zł) otrzymali posłowie na sejm warszawski 1572 r. (zob. I. Kaniewska, „Strawne pieniądze”, s. 48 (tab. „Wypłaty strawnego wysokość stawki na jednego posła"). 
Posłowie koronni na sejm koronacyjny $1574 \mathrm{r}$.

Jako podstawę do opracowania niniejszego wykazu przyjęto SK. Posłów wymienionych w SW oznaczono podkreśleniem, a w przypisie podano informację, czy odbiór strawnego pokwitowali osobiście, czy przez zastępców oraz (o ile taka informacja została podana) w jakiej wysokości. Z SK przejęto również podział posłów na województwa oraz (ewentualnie) ziemie i powiaty. W przypadku kilku województw informacje z SW pozwoliły doprecyzować, z których sejmików posłowali poszczególni posłowie. W takim przypadku podkreślono również nazwę danej jednostki terytorialnej. W przypisach podano podstawowe informacje o zidentyfikowanych osobach oraz podstawową literaturę przedmiotu ${ }^{21}$.

\section{Województwo krakowskie}

$\frac{\frac{\text { Stanisław Szafraniec z Pieskowej Skały }}{\text { Stanisław Dembiński }}{ }^{23}}{{\frac{\text { Piotr Strzała }}{\text { Jan Kmita }^{25}}}^{\text {San }^{24}}}$

${ }^{21} \mathrm{~W}$ przypisach do spisu wykorzystano (poza wskazanymi w instrukcji dla autorów oraz użytymi już w niniejszym artykule) następujące skróty: A. Boniecki, Herbarz polski, Warszawa 1899-1913 (Bon.); K. Niesiecki, Herbarz polski, wyd. J.N. Bobrowicz, Lipsk 1839-1846 (Nies.); B. Paprocki, Herby rycerstwa polskiego na pięcioro ksiag rozdzielone, wyd. K.J. Turowski, Kraków 1858 (Paprocki); S. Uruski, A. Kosiński, A. Włodawski, Rodzina. Herbarz szlachty polskiej, Warszawa 1904-1938 (Uruski); Urzędnicy. Dodatkowo użyto następujących skrótów: burg. - burgrabia, chor. - chorąży, cz. - cześnik, gr. - grodzki, GWP - starosta generalny wielkopolski, klan - kasztelan, kor. - koronny, marsz. marszałek; pcz. - podczaszy, pis. - pisarz, pkom. - podkomorzy, psta. - podstarości, psęd. - podsędek, pstol. - podstoli, sęd. - sędzia, sta - starosta, stol. - stolnik, wlki wielki, wda - wojewoda, z. - ziemski.

${ }^{22}$ Stanisław Szafraniec z Pieskowej Skały h. Starykoń (zm. 1598), klan biecki 15691576, klan sandomierski 1576, wda sandomierski 1581-1587 (H. Kowalska, Stanisław Szafraniec z Pieskowej Skały, OiRP 3,1958, s. 99-131; Urzędnicy, t. 4, z. 2, s. 261).

${ }^{23}$ Stanisław Dembiński h. Rawicz (zm. 1586), syn Walentego kanclerza wlkiego kor., sta chęciński 1564-1589, żupnik ruski 1571-1586 (W. Budka, Dembiński Stanisław, PSB, t. 5, Kraków 1939-1946, s. 74-75; Urzędnicy, t. 4, z. 3, s. 176). W SW pokwitował osobiście odbiór strawnego w rubryce dla posłów z województwa sandomierskiego (błędnie).

${ }^{24}$ Piotr Strzała z Sosnowic h. Kotwicz, sęd. zatorski 1564-1604, burg. krakowski 1571-1588 (Urzędnicy, t. 4, z. 2, s. 260). W SK wymieniony jedynie z urzędu sęd. zatorskiego. W SW pokwitował osobiście.

${ }^{25}$ Jan Kmita z Woli, h. Szreniawa (1517-1588), pis. z. krakowski 1560-1588, burg. krakowski 1563-1564 (W. Budka, Kmita Jan, PSB, t. 13, Wrocław 1967-1968, s. 92; Urzędnicy, t. 4, z. 2, s. 231). W SK wymieniony tylko z urzędu pis. z. krakowskiego. W SW pokwitował osobiście. 
Marian Przyłęcki ${ }^{26}$

$\overline{\text { Stanisław Taszycki }}{ }^{27}$

Sebastian Pisarzowski ${ }^{28}$

Województwo poznańskie

Stanisław Wysocki ${ }^{29}$

Piotr Potulicki ${ }^{30}$

Stanisław Górka ${ }^{31}$

Wojciech Sędziwój Czarnkowski ${ }^{32}$

Stanisław Sędziwój Czarnkowski ${ }^{33}$

Jerzy Latalski ${ }^{34}$

${ }^{26}$ Marian (Marcjan) Przyłęcki h. Szreniawa (zm. 1583), sęd. gr. krakowski i burg. krakowski 1564-1571, sta wolbromski 1564-1583 (I. Kaniewska, Przyłęcki Marian, PSB, t. 29, Wrocław 1986, s. 197-199; Urzędnicy, t. 4, z. 2, s. 253). W SW pokwitował osobiście.

27 Stanisław Taszycki z Lusławic (PZK, s. 222). W SK wymieniony tylko z nazwiska. W SW pokwitował osobiście.

${ }_{28}$ Sebastian Pisarzowski (Pisarzewski) h. Starykoń, pis. (a nie psęd. jak w SK) z. zatorski 1563-83 (Urzędnicy, t. 4, z. 2, s. 251). W SK wymieniony w cedule dołączonej do spisu (zob. uwagi w tekście). W SW pokwitował osobiście.

${ }^{29}$ Stanisław Wysocki z Budzisławia h. Dryja (zm. 1575/1576), pis. z. kaliski 15511554, sęd. z. kaliski 1554-1568, klan biechowski 1568-1571 i lądzki 1572-1575 (E. Opaliński, Rodziny wielkosenatorskie w Wielkopolsce, na Kujawach i na Mazowszu za Zygmunta III. Podstawy karier, Warszawa 2007, s. 58, przyp. 94; Urzędnicy, t. 1, z. 2, s. 236).

30 Piotr Potulicki z Chodzieży h. Grzymała (zm. 1606), klan przemętski 1569-1576, wda płocki 1576-1581, wda brzeski 1581-1584, wda kaliski 1584-1606 (E. Opaliński, op. cit., s. 58, przyp. 94; S. Leitgeber, Potulicki Piotr, PSB, t. 28, Wrocław 1984-1985, s. 252255; Urzędnicy, t. 1, z. 2, s. 224).

${ }^{31}$ Stanisław Górka h. Łodzia (zm. 1592), wda poznański 1576-1592, sta buski, kolski, ujski (E. Opaliński, op. cit., s. 92, przyp. 69; K. Lepszy, Górka Stanisław, PSB, t. 8, Wrocław 1959-1960, s. 416-424; Urzędnicy, t. 1, z. 2, s. 203).

32 Wojciech Sędziwój Czarnkowski h. Nałęcz (zm. 1578), GWP 1563-1578 (A. Dembińska, Czarnkowski Wojciech Sędziwój, PSB, t. 4, Kraków 1938, s. 225-226; Urzędnicy, t. 1, z. 2, s. 198). W SW pokwitował osobiście odbiór strawnego dwukrotnie: w miejscu przewidzianym dla posłów z województwa poznańskiego (poprawnie) oraz w rubryce dla posłów z województwa mazowieckiego błędnie, pokwitowanie przekreślone).

33 Stanisław Sędziwój Czarnkowski h. Nałęcz (1526-1602), brat Wojciecha Sędziwoja (zob. przyp. 32), referendarz wlki kor. 1567-1576, sta płocki 1572-1576, marsz. izby poselskiej na sejmie lubelskim 1569 r. (K. Lepszy, Czarnkowski Stanisław Sędziwój, PSB, t. 4, s. 221-224; Urzędnicy, t. 10, s. 163; K. Chłapowski, Starostowie w Wielkopolsce, na Kujawach i Mazowszu 1565-1696. Materiały źródłowe, Warszawa 2007, s. 564). W SW odbiór strawnych (80 zł) pokwitował „Stanisław Pokliaticzki sługa J(eg)o Miłości P. Referendarza wedlie czeduły".

${ }^{34}$ Jerzy Latalski h. Prawdzic (1541-1602), wojewodzic poznański, syn Janusza (Jana) (biogram ojca: I. Kaniewska, Latalski Janusz, PSB, t. 16, Wrocław 1971, s. 564). W SW pokwitował osobiście. 


\section{Województwo sandomierskie \\ Andrzej Firlej ${ }^{35}$ \\ Bartłomiej Żeleński ${ }^{36}$ \\ Andrzej Gołuchowski ${ }^{37}$ \\ Leonard Strasz $^{38}$ \\ Mikołaj Koniecpolski ${ }^{39}$ \\ Jan Oleśnicki $^{40}$}

\section{Województwo kaliskie}

Bartłomiej Suchorzewski ${ }^{41}$

Stanisław Przyjemski ${ }^{42}$

35 Andrzej (a nie jak w SK: Mikołaj) Firlej z Dąbrowicy h. Lewart (zm. 1585), syn Piotra, sta sandomierski 1569-1585; klan lubelski (1576-1585) (K. Lepszy, Firlej Andrzej, PSB, t. 6, Kraków 1948, s. 474-475; Urzędnicy, t. 4, z. 3, s. 178). W SW pokwitował osobiście.

${ }^{36}$ Bartłomiej (Bartosz) Żeleński h. Ciołek (zm. przed 20 XI 1580), pkom. sandomierski 1564-1569, sta stężycki 1569-1580 (Urzędnicy, t. 4, z. 3, s. 224; Nies., t. 10, s. 560). W SK wymieniony jedynie z urzędu sty stężyckiego. W SW pokwitował osobiście.

37 Andrzej Gołuchowski h. Leliwa (zm. 1591), łowczy sandomierski 1566-1569, wojski sandomierski 1570-1590, pkom. sandomierski 1579-1591 (H. Kowalska, Gotuchowski Andrzej, PSB, t. 8, s. 261-262; Urzędnicy, t. 4, z. 3, s. 180). W SK wymieniony tylko z urzędu wojskiego sandomierskiego. W SW pokwitował osobiście odbiór strawnego dwukrotnie: w miejscu przewidzianym dla posłów z województwa krakowskiego (błędnie) oraz w rubryce dla posłów z województwa sandomierskiego (poprawnie).

${ }^{38}$ Leonard (Lenart) Strasz h. Odrowąż (zm. po 18 I 1588), burg. krakowski 15631577 (I. Kaniewska, Strasz Leonard, PSB, t. 44, Warszawa-Kraków 2006-2007, s. 206-208; Urzędnicy, t. 4, z. 2, s. 260). W SK wymieniony jedynie z nazwiska. W SW pokwitował osobiście.

${ }^{39}$ Mikołaj Koniecpolski h. Pobóg (zm. przed 1587), syn Stanisława, klan rozpierski, posłował na sejmy w latach 1553, 1569 (z woj. sandomierskiego) oraz 1563/1564 (z woj. krakowskiego; zob. I. Kaniewska, Koniecpolski Mikołaj, PSB, t. 13, s. 522). W SK wymieniony jedynie z nazwiska. W SW pokwitował osobiście.

${ }^{40}$ Jan Oleśnicki h. Dębno (zm. 1578-1579), syn Jana Jaworskiego z Oleśnicy, był m.in. posłem na sejm lubelski 1566 r. (PZK, s. 166; J. Pielas, Oleśniccy herbu Dębno w XVI-XVII wieku. Studium z dziejów zamożnej szlachty doby nowożytnej, Kielce 2007, s. 173 oraz tabl. 2; idem, Działalność Oleśnickich jako przedstawicieli sejmiku województwa sandomierskiego w XVI-XVII w., „Między Wisłą a Pilicą. Studia i materiały historyczne” 1, 2000, s. 120). W SK wymieniony jedynie z nazwiska. W SW pokwitował osobiście.

${ }^{41}$ Bartłomiej Suchorzewski h. Zaręba, pkom. kaliski 1565-1586 (Urzędnicy, t. 1, z. 2, s. 236).

${ }^{42}$ Stanisław Przyjemski h. Rawicz (zm. 1595), marsz. nadworny 1588-1593, marsz. wlki kor. 1593-1595 (W. Dworzaczek, H. Kowalska, Przyjemski Stanisław, PSB, t. 29, s. 181185; Urzędnicy, t. 10, s. 198). W SW pokwitował osobiście. 
Marcin Ostroróg ${ }^{43}$

Stefan Grudziński ${ }^{44}$

Mikołaj Głogiński $^{45}$

Jan Ostroróg ${ }^{46}$

Województwo sieradzkie ${ }^{47}$

Świętosław Lipicki ${ }^{48}$

Piotr Bużeński ${ }^{49}$

Stanisław Sasin Karśnicki ${ }^{50}$

Stanisław Przerębski ${ }^{51}$

Ziemia wieluńska

Abraham Giżycki ${ }^{52}$

Gabriel Masłowski $^{53}$

${ }^{43}$ Marcin Ostroróg z Lwówka (Lwowski) h. Nałęcz (zm. 1590/1591), klan kamieński 1581-1590 (W. Dworzaczek, Ostroróg Lwowski Marcin, PSB, t. 24, Wrocław 1979, s. 513-514; Urzędnicy, t. 1, z. 2, s. 222). W SW pokwitował osobiście.

${ }^{44}$ Stefan Grudziński h. Grzymała (zm. 1588), klan nakielski 1576-1588, sta wałecki (K. Lepszy, Grudziński Stefan, PSB, t. 9, Wrocław 1960-1961, s. 47-48; Urzędnicy, t. 1, z. 2, s. 294). W SW pokwitował osobiście.

${ }^{45}$ Mikołaj Głogiński h. Ostoja (zm. ok. 1585), pcz. kaliski 1577-1579 (Urzędnicy, t. 1, z. 2, s. 201). W SW wpisany dwukrotnie (SW, s. 278). Wpisy dokonano dwiema różnymi rękami, oba bez formuły potwierdzającej własnoręczność podpisu. Następują one bezpośrednio po sobie, z tym, że pierwszy z nich został przekreślony).

${ }^{46}$ Jan Ostroróg, h. Nałęcz (1545/45-1582), cz. kor. 1576-1582, sta stężycki 15801582 (M.B. Topolska, Ostroróg Jan, PSB, t. 24, s. 505-506; Urzędnicy, t. 1, z. 2, s. 222; Urzędnicy, t. 10, s. 192).

${ }^{47}$ W SW nazwiska posłów z województwa sieradzkiego wpisano tą samą ręką.

48 Świętosław Lipicki h. Poraj (zm. po marcu 1575), klan konarski sieradzki 1553 2 IV 1574 (nominacja na klana rozpierskiego), klan rozpierski do 1575 (Urzędnicy, t. 2, z. 2, s. 269).

${ }^{49}$ Piotr Bużeński h. Poraj (ok. 1512 - 4 V 1579 lub przed 22 I 1582, zob. PZK, s. 112, przyp. 107), sęd. sieradzki 1557-1578 (Urzędnicy, t. 2, z. 2, s. 246).

50 Stanisław Sasin Kraśnicki h. Jastrzębiec (zm. po 29 I 1602), psęd. sieradzki 15701578, burg. krakowski 1574-1576, sęd. sieradzki 1579-1602 (Urzędnicy, t. 2, z. 2, s. 261).

51 Stanisław Przerębski h. Nowina (ok. 1540-1607), klan sieradzki 1603-1607 (J. Byliński, Przerębski Stanisław, PSB, t. 29, s. 1-2; Urzędnicy, t. 2, z. 2, s. 283).

52 Abraham Giżycki h. Nałęcz (zm. 1582/1583), burg. ostrzeszowski 1542-1544, psta. ostrzeszowski 1545-1546, surogator ostrzeszowski 1547-1563, sęd. wieluński 1563-1582 (Urzędnicy, t. 2, z. 2, s. 254). W SK wymieniony jedynie z urzędu sęd. wieluńskiego.

53 Gabriel Masłowski h. Samson (zm. przed 17 IX 1585), psta. i wojski wieluński 1562-1581 (R. Rosin, Masłowski Gabriel, PSB, t. 20, Wrocław 1975, s. 127; Urzędnicy, t. 2, z. 2, s. 273). W SW pokwitował osobiście. 


\section{Województwo łęczyckie \\ Walenty Ponętowski ${ }^{54}$ \\ Tomasz Dembowski ${ }^{5}$ \\ $\overline{\text { Mikołaj Małachowski }}^{56}$ \\ Jan Bełdowski ${ }^{57}$}

Województwo brzeskie ${ }^{58}$

Stanisław Sierakowski ${ }^{59}$

Wojciech Niemojewski ${ }^{60}$

\section{Województwo inowrocławskie ${ }^{61}$ \\ Adam Baliński ${ }^{62}$ \\ Mikołaj Rożyński ${ }^{63}$}

${ }^{54}$ Walenty Ponętowski h. Leszczyc (zm. po 1 I 1588), pkom. łęczycki 1573-1586 (A. Lipski, Ponętowski Walenty, PSB, t. 27, Wrocław 1982-1983, s. 405-406; Urzędnicy, t. 2, z. 2, s. 292). W SW pokwitował osobiście.

55 Tomasz Dembowski z Dembowej Góry h. Jelita (zm. po 10 V 1576), cz. łęczycki 1563-1565, sęd. łęczycki 1565-1576 (Urzędnicy, t. 2, z. 2, s. 250). W SW pokwitował osobiście 48 zł.

${ }^{56}$ Mikołaj Małachowski h. Nałęcz (zm. 1575), dworzanin i sekretarz królewski 1558-1575, klan spicmirski 1574-1575 (H. Kowalska, Małachowski Mikołaj, PSB, t. 19, Wrocław 1986, s. 408; Urzędnicy, t. 2, z. 2, s. 273). W SW pokwitował osobiście.

${ }^{57}$ Jan Bełdowski h. Jastrzębiec (Bon., t. 1, s. 155-156). W SW pokwitował osobiście $48 \mathrm{zł}$.

${ }^{58}$ W SK posłów z województw brzeskiego i inowrocławskiego wpisano razem, zaznaczając, że wybrano ich na wspólnym sejmiku („Brestensis et Iuniwladensis. Ex uno conventu"). Poniżej wpisano czterech posłów. W SW mamy natomiast dwie odrębne pozycje: „Pallatinatus Brestensis” (brak pokwitowań) i „Pallatinatus Iuniwladensis” (dwa pokwitowania). Dzięki temu można pokusić się wskazanie, którzy z posłów mieli reprezentować poszczególne województwa.

59 Stanisław Sierakowski z Bogusławic h. Ogończyk (1534-1596), chor. brzeski 15591560, pkom. dobrzyński 1563-1565, klan rypiński 1568-1569, sta kowalski 1572-1576, klan lądzki 1577-1596, sta przedecki 1576-1596 (A. Kamieński, Sierakowski Stanisław, PSB, t. 37, Warszawa-Kraków 1996, s. 299-302; Urzędnicy, t. 6, z. 2, s. 266).

60 Wojciech Niemojewski h. Szeliga (zm. po 20 I 1588), sęd. gr. inowrocławski, pkom. inowrocławski 1577-1588 (J. Płokarz, Jan Niemojewski. Studium z dziejów arian w Polsce, „Reformacja w Polsce” 2, 1922, s. 71-75; J. Tazbir, Niemojewski Jakub, PSB, t. 23, Wrocław 1978, s. 10-13 (biogram brata); Urzędnicy, t. 6, z. 2, s. 254).

${ }^{61}$ Zob. przyp. 58.

62 Adam Baliński z Chomiąży Szlacheckiej h. Ogończyk (zm. przed 15 XI 1602), chor. inowrocławski 1575-1582, sta kruszwicki 1582-1601, klan bydgoski 1590-1601 (Urzędnicy, t. 6, z. 2, s. 215). W SW pokwitował osobiście 48 zł.

${ }^{63}$ Mikołaj Rożyński h. nieznanego (zm. 1599), psęd. inowrocławski 1578-1586, sta inowrocławski 1586-1598 (Urzędnicy, t. 6, z. 2, s. 263). W SW pokwitował osobiście 48 zł. 
Ziemia dobrzyńska ${ }^{64}$

Walenty Czerski ${ }^{65}$

Andrzej Cząbski ${ }^{66}$

\section{Ziemia kijowska}

\begin{tabular}{l}
$\frac{\text { Konstanty Ostrogski }}{{ }^{67}}$ \\
Iwan Olizar Wołczkiewicz $^{68}$ \\
\hline Iwan Proskura Suszczański \\
\end{tabular}

\section{Województwo ruskie ${ }^{70}$}

${ }^{64}$ Przed sejmem odprawiono w ziemi dobrzyńskiej dwa sejmiki, na których wybrano posłów. Na pierwszym, w którym uczestniczyła większość szlachty, wybrano Walentego Czerskiego i Andrzeja Cząbskiego (Szumskiego). Na drugim wyznaczono dodatkowo trzech posłów: Michała Działyńskiego, Łukasza Kretkowskiego i Zygmunta Sumińskiego. Dodatkowi posłowie mieli jedynie uczestniczyć w koronacji. Podczas obrad sejmowych zobowiązano ich do powstrzymania się od udziału w pracach izby (A. Dembińska, Czerski Walenty, PSB, t. 4, s. 348; PZK, s. 220, przyp. 208). W świetle SK i SW wynika, że pozbawiono ich również prawa do strawnego.

${ }^{65}$ Walenty Czerski h. Ogończyk (zm. ok. 1591), szafarz poborów z. dobrzyńskiej 1590 (A. Dembińska, Czerski Walenty).

${ }^{66}$ Andrzej Cząbski (Czampski, Czapski, Czempski, Szumski) h. Grzymała (zm. 1602), psęd. dobrzyński 1576-1596 (Urzędnicy, t. 6, z. 2, s. 223). W SW pokwitował osobiście.

${ }^{67}$ Konstanty Ostrogski h. własnego (zm. 1588), syn Konstantyna Wasyla, wdy kijowskiego, krajczy litewski 1580, sta włodzimierski 1580-1588 (T. Chynczewska-Hennel, Ostrogski Konstanty Wasyl, PSB, t. 24, s. 495 (biogram ojca); T. Kempa, Dzieje rodu Ostrogskich, Toruń 2002, s. 123-126; Urzędnicy, t. 11, s. 227). W SW odbiór pieniędzy (48 zf) pokwitował za Ostrogskiego Iwan Suszczański (zob. przyp. 69).

${ }^{68}$ Iwan Olizar Wołczkiewicz h. Choragwie (ok. 1520-1577; J. Dzięgielewski, Olizar Adam, PSB, t. 23, s. 805 (biogram syna); H. Litwin, Równi do równych. Kijowska reprezentacja sejmowa 1569-1648, Warszawa 2009, s. 42-44; idem, Rody pańskie Kijowszczyzny 1569-1648. Status majątkowy, „Przegląd Wschodni” 8, 2002, 2 (30), s. 245-247; K. Mazur, W strone integracji z Korona. Sejmiki Wołynia i Ukrainy w latach 1569-1648, Warszawa 2006, s. 200). W SW pokwitował osobiście 48 zł.

${ }^{69}$ Iwan Proskura Suszczański h. Krzyżostrzał (zm. 1595; Nies., t. 7, s. 502; H. Litwin, Równi do równych, s. 47; idem, Rody pańskie, s. 256-257; K. Mazur, op. cit., s. 200). W SW pokwitował osobiście $48 \mathrm{zł}$.

${ }^{70}$ W PZK (s. 222) ustalono nazwiska trzech posłów z województwa ruskiego: Jana Biejkowskiego, Stanisława Drohojowskiego oraz Jana Tomasza Drohojowskiego h. Korczak (1535-1605), sekretarza królewskiego, sty przemyskiego (1578-1605) i referendarza wlk kor. (1589-1605; K. Lepszy, Drohojowski Jan Tomasz, PSB, t. 5, s. 382-385; Urzędnicy, t. 3, z. 1, s. 238), którego w SK nie uwzględniono. Podstawą do zaliczenia tego ostatniego w poczet posłów jest wzmianka u Orzelskiego I, s. 228-229. Możliwe, że Orzelski pomylił imię Stanisława Drohojowskiego bądź przypisał jego nazwisko jednemu z posłów ruskich o imieniu Jan: wspomnianemu Janowi Biejkowskiemu, Janowi Sieniawskiemu lub Janowi Białoskórskiemu. W SW podział na ziemie: przemyską, sanocką, chełmską i halicką. W SK brak podziału na powiaty - posłowie wpisani pod „Terrae Russiae”. 
Ziemia przemyska

Jan Biejkowski $^{71}$

Stanisław Drohojowski ${ }^{72}$

Ziemia sanocka

Andrzej Niedrwicki ${ }^{73}$

Gabriel Domaradzki $^{74}$

Ziemia chełmska

Zygmunt Zaklina Czyżowski $^{75}$

Wacław Uhrowiecki ${ }^{76}$

Ziemia halicka

Jan Białoskórski ${ }^{77}$

Paweł Skotnicki $^{78}$

$\overline{\text { Jan Sieniawski }^{79}}$

${ }^{71}$ Jan Biejkowski h. Jastrzębiec, stol. przemyski 1571-1590, sta gąbiński 1581 (Urzędnicy, t. 3, z. 1, s. 308; K. Przyboś, Reprezentacja sejmowa ziemi przemyskiej w latach 1573-1695, „Rocznik Przemyski” 34, 1998, 1, s. 21). W SW pokwitował osobiście.

${ }^{72}$ Stanisław Drohojowski (Drohojewski, Drojewski) h. Korczak (1529-1583), klan przemyski 28 VII 1574 - 1582 (S. Bodniak, Drohojowski Stanisław, PSB, t. 5, s. 388; Urzędnicy, t. 3, z. 1, s. 326; K. Przyboś, op. cit., s. 23, nr 12). W SW pokwitował osobiście.

${ }^{73}$ Andrzej Niedrwicki h. Ogończyk, pkom. sanocki 1580-1582, klan połaniecki 1582 (Urzędnicy, t. 3, z. 1, s. 370). W SK wymieniony jedynie z nazwiska. W SW pokwitował osobiście.

${ }^{74}$ Gabriel Domaradzki h. Gryf (Nies., t. 3, s. 368). W SW pokwitował osobiście.

${ }^{75}$ Zygmunt Zaklina Czyżowski h. Topór (zm. 1585), klan połaniecki 1584, klan bełski 1584 (Urzędnicy, t. 3, z. 2, s. 224). W SK wymieniony jedynie z nazwiska. W SW pokwitował osobiście.

${ }^{76}$ Wacław Uhrowiecki h. Suchekomnaty (W. Czarnecki, Uhrowieccy h. Suchekomnaty w ziemi chetmskiej do połowy XVI wieku do połowy XVI wieku, ,Wschodni Rocznik Humanistyczny" 6, 2009, s. 9-25; idem, Szlachta ziemi chetmskiej do połowy XVI wieku, Białystok 2012, s. 253-272, s. 394 (tabl. 14); Urzędnicy, t. 3, z. 2, s. 283). W SK wymieniony jedynie z nazwiska. W SW pokwitował osobiście w rubryce „Terrae Chelmensis”.

77 Jan Białoskórski h. Abdank, pcz. halicki 1566-1569 (Urzędnicy, t. 3, z. 1, s. 307). W SW pokwitował osobiście.

78 Paweł Skotnicki h. Grzymała (zm. ok. 1597), chor. halicki 1569-1590 (I. Kaniewska, Skotnicki Pawet, PSB, t. 38, Warszawa-Kraków 1997-1998, s. 306-307; Urzędnicy, t. 3, z. 1, s. 388). W SW pokwitował osobiście.

${ }^{79}$ Jan Sieniawski h. Leliwa (zm. 1583), syn Mikołaja, hetmana wlkiego kor. i wdy ruskiego, sęd. z. halicki 1583 (M. Plewczyński, Sieniawski Mikołaj, PSB, t. 37, s. 125 (biogram ojca); Urzędnicy, t. 3, z. 1, s. 387). W SW pokwitował osobiście. 
Pozostali posłowie z województwa ruskiego

Mikołaj Herburt ${ }^{80}$

Stanisław Żółkiewski ${ }^{81}$

Mikołaj Kuropatwa ${ }^{82}$

Piotr Borecki ${ }^{83}$

Dubrawski ${ }^{84}$

\section{Wołyń}

Aleksander Markowicz Żorawnicki ${ }^{85}$ Hawryło Wasylewicz Bokij Pieczychwostski ${ }^{86}$ Bohdan Kościuszko Chobołtowski ${ }^{87}$

${ }^{80}$ Mikołaj Herburt h. własnego (po 1524-1593), pkom. przemyski 1568-1570, sta lwowski 1570-1593, klan halicki 1585-1589, klan przemyski 1589-1593 (R. Żelewski, Herburt Mikołaj, PSB, t. 9, s. 447-449; Urzędnicy, t. 3, z. 1, s. 338). W SW pokwitował osobiście.

${ }^{81}$ Brak w SK i SW urzędu utrudnia identyfikację posłującego członka rodu Żółkiewskich h. Lubicz o imieniu Stanisław. Pod uwagę trzeba brać: 1) Stanisława Żółkiewskiego h. Lubicz, syna Stanisława (zm. 1588), klana halickiego 1580-1581, wojewodę bełskiego 1581, wojewodę ruskiego 1585-1588 (Nies., t. 10, s. 183; Urzędnicy, t. 3, z. 1, s. 338) lub 2) jego syna Stanisława Żółkiewskiego h. Lubicz (1547-1620) sekretarza królewskiego, klana lwowskiego 1590-1608, wdę kijowskiego 1608, hetmana polnego 1588-1618 i wlk kor. 1618-1620, kanclerza wlk kor. 1618-1620 (J. Ternes, Przyczynki do genealogii Źótkiewskich w XVI w., „Rocznik Lubelskiego Towarzystwa Genealogicznego" 4, 2012, s. 84-95; Urzędnicy, t. 3, z. 1, s. 338). Ponieważ w SW poseł pokwitował osobiście odbiór należnych pieniędzy, można pokusić się o rozpoznanie ręki poprzez porównanie z zachowanymi autografami ww. Analiza taka skłania do identyfikowania posła na sejm koronacyjny z przyszłym hetmanem i kanclerzem wlk kor. Zob. o początkach kariery politycznej Stanisława Żółkiewskiego: J. Urwanowicz, Od towarzysza obrony potocznej do kasztelana halickiego. Pierwszy etap kariery Stanisława Żółkiewskiego (1520-1580), w: Historia testis temporum, s. 183-198.

${ }^{82}$ Mikołaj Kuropatwa z Pałahicz h. Szreniawa, wojski halicki 1555-1582 (Urzędnicy, t. 3, z. 1, s. 355).

${ }^{83}$ Piotr Borecki h. Hołobok, pcz. halicki 1587-1604 (Urzędnicy, t. 3, z. 1, s. 311).

${ }^{84}$ Brak w SK imienia i urzędu utrudnia identyfikację posłującego członka rodu Dubrawskich h. Sas. Pod uwagę trzeba brać: 1) Andrzeja, wojskiego stryjskiego ok. 1593; 2) Jana miecznika lwowskiego 1553-1577 oraz 3) Tomasza (zm. 1602) psęd. halickiego 1567-1578 (Urzędnicy, t. 3, z. 1, s. 327).

85 Aleksander Markowicz Żorawnicki (Żurawicki) h. Korczak (zm. 1580), marsz. hospodarski 1560, klucznik łucki 1563-1580, horodniczy łucki 1563-1580, sta łucki 15761580 (Urzędnicy, t. 3, z. 5, s. 188; K. Mazur, op. cit., s. 41). W SW pokwitował osobiście.

${ }^{86}$ Hawryło (Gabriel) Wasylewicz Bokij Pieczychwostski h. własnego (zm. 1577) sęd. łucki 1566-1577 (O. Halecki, Bokiej Gabriel, PSB, t. 2, Kraków 1936, s. 243-244 (z błędną datą śmierci); Urzędnicy, t. 3, z. 5, s. 156; K. Mazur, op. cit., s. 45). W SW pokwitował osobiście.

87 Bohdan Kościuszko Chobołtowski h. własnego, psęd. włodzimierski 1566, sęd. włodzimierski 1566-1584 (Urzędnicy, t. 3, z. 5, s. 168). 
Jan Jeło-Maliński ${ }^{88}$

\section{Podole $^{89}$}

Powiat kamieniecki

Mikołaj Tworowski ${ }^{90}$

Stanisław Lanckoroński ${ }^{91}$

Mikołaj Herburt ${ }^{92}$

Stanisław Czermiński ${ }^{93}$

Województwo lubelskie
$\frac{\text { Piotr Kaszowski }}{{ }^{94}}$
Adam Gorajski $^{95}$
Wojciech Męciński $^{96}$

${ }^{88}$ Jan Jeło-Maliński h. Pietyrog, być może tożsamy z marsz. sejmiku relacyjnego ziemi wołyńskiej (sierpień 1607) i/lub z nieznanym z imienia Jeło-Malińskim, posłem litewskim na sejm warszawski 1564 r. (K. Mazur, op. cit., s. 431; Nies., t. 6, s. 328). W SW pokwitował osobiście $48 \mathrm{zł}$.

${ }^{89}$ W PZK (s. 223) wskazano jako prawdopodobnego posła z Podola Stanisława Suchorabskiego h. Ostoja, stol. kamienieckiego (Urzędnicy, t. 3, z. 3, s. 135) nie wymienionego w SK i SW.

${ }_{90}$ Mikołaj Tworowski z Buczacza i Tworowa h. Pilawa (zm. 1595), pkom. kamieniecki 1570-1595, rotmistrz królewski 1571-1573, sta barski 1571-1588 (Urzędnicy, t. 3, z. 3, s. 238; Bon., t. 2, s. 221; Paprocki, s. 382-383). W SW pokwitował osobiście.

${ }_{91}$ Stanisław Lanckoroński z Brzezia h. Zadora (zm. 1592), syn Hieronima, rotmistrz jazdy koronnej, sta skalski 1566, klan halicki 1589-1592 (H. Kotarski, Lanckoroński Stanisław, PSB, t. 16, s. 452-453; Urzędnicy, t. 3, z. 3, s. 215). W SW pokwitował osobiście.

${ }_{92}$ Mikołaj Herburt h. własnego, (ok. 1544-1602), chor. lwowski 1577-1581, pkom. halicki 1581-1587, wda podolski 1588, wda ruski 1588-1602 (R. Żelewski, Herburt Mikołaj, PSB, t. 9, Wrocław 1960-1961, s. 449-450; Urzędnicy, t. 3, z. 3, s. 203). W SW pokwitował osobiście.

${ }_{93}$ Stanisław Czermiński z Czermnej h. Ramułt, kandydat na pisarstwo kamienieckie w 1551 r. (Urzędnicy, t. 3, z. 3, s. 196).

${ }_{94}$ Piotr Kaszowski z Wysokiego h. Janina (zm. 1592), sęd. z. lubelski (1 III 1574 [nominacja] - 1592; Urzędnicy, t. 4, z. 4, s. 46, 114). W SW pokwitował osobiście

${ }_{95}$ Adam (a nie jak w SK: Jerzy) Gorajski h. Korczak (zm. 1591), podkom. lubelski 1589-1591 (D. Kupisz, Gorajscy w XV-XVI wieku. Studium z dziejów awansu społeczno-politycznego rodziny szlacheckiej, „Almanach Historyczny” 3, 2001, s. 29-31). W SW pokwitował osobiście.

${ }^{96}$ Wojciech Męciński h. Poraj (potwierdzony źródłowo m.in. Archiwum Państwowe, Lublin, Księgi grodzkie lubelskie. Zapisy, t. 24, k. 585v-586). W SK wymieniony jedynie z nazwiska. W SW pokwitował osobiście. 
Województwo bełskie

Jan Zamoyski ${ }^{97}$

Piotr Cieciszewski ${ }^{98}$

Stanisław Trojan Rachański ${ }^{99}$

Easzcz $^{100}$

Ziemia płocka ${ }^{101}$

Wojciech Wilkanowski ${ }^{102}$

Hieronim Gostomski ${ }^{103}$

Jakub Łysakowski ${ }^{104}$

Wojciech Staroźrebski ${ }^{105}$

97 Jan Zamoyski h. Jelita (1542-1605), sta bełski 1572-1605, sekretarz królewski 1565, podkanclerzy 1576-1578 i kanclerz wlki kor. 1578-1605, hetman wlki kor. 15811605 (Urzędnicy, t. 10, s. 216).

98 Piotr Cieciszewski (Cieciszowski) h. Kolumna, sta grabowski 1541-1591 (Urzędnicy, t. 3, z. 2, s. 223).

99 Stanisław Trojan Rachański h. Jastrzębiec, chor. bełski 1544-1585, pkom. bełski 1585-1595 (Urzędnicy, t. 3, z. 2, s. 271). W SW pokwitował osobiście.

100 Identyfikacja niejednoznaczna. Posłem mógł być zarówno Aleksander (a nie jak w SK: Ambroży) Łaszcz z Tuczap h. Prawdzic (zm. 1584), klan czerski 1576-1584, pkom. bełski 1544-1570 (I. Kaniewska, Łaszcz Aleksander, PSB, t. 18, Wrocław 1973, s. 259-260; Urzędnicy, t. 3, z. 2, s. 244) lub Aleksander (a nie jak w SK: Ambroży) Łaszcz z Tuczap h. Prawdzic (zm. przed 6 II 1602), chor. bełski 1585-1602 (Urzędnicy, t. 3, z. 2, s. 244).

101 W SK adnotacja: „sex sunt electi et tres [--] more aulico esse debet”.

102 Wojciech Wilkanowski h. Lis (zm. ok. 1598), pkom. płocki 1566-1582, klan płocki 1582-1595, od 1595 wda rawski (E. Opaliński, op. cit., s. 74, 181, 252).

${ }^{103}$ Hieronim Gostomski z Leżenic h. Nałęcz (zm. 1609), dworzanin królewski, marsz. izby poselskiej na sejmie 1590 r., wojewoda poznański (1592-1609), sta sandomierski (1597-1602 (K. Lepszy, Gostomski Hieronim, PSB, t. 8, s. 364-366). W SK występuje jako pkom. sochaczewski („Hyeronimus Gosszomski succamerarius Sochaczoviensis”). W literaturze przedmiotu jednakże z Gostomskim wiązane jest jedynie pkom. rawskie i w źródłach jest wzmiankowany z tym urzędem dopiero w 1576 r. Możliwe, że spis pozwala (o ile przyjmiemy, że mamy do czynienia z błędem pisarza) przesunąć jego nominację na ten urząd przed 24 kwietnia 1574 (koniec sejmu koronacyjnego). Jednakże poza edytowanym spisem Gostomski pojawia się z urzędem pkom. sochaczewskiego także jeszcze w księdze podskarbińskiej, gdzie pod rokiem 1571 występuje „Gostomski Hieronim z Leżenic, podkomorzy sochaczewski, dworzanin JKMci, herbu Nałęcz” (ed. F. Piekosiński, Księga podskarbińska nr 8 z lat 1571-1575, w: Wypisy heraldyczne z ksiag poborowych, „Rocznik Towarzystwa Heraldycznego" 2, 1910, s. 31, poz. 146). Możliwe więc, że był on rzeczywiście pkom. sochaczewskim między 1571-1574, by później postąpić na urząd pkom. rawskiego.

104 Jakub Łysakowski h. Lubicz (zm. luty 1575; Bon., t. 16, s. 185). W SW pokwitował osobiście.

105 Wojciech Staroźrebski h. Dołęga, najprawdopodobniej jeden z przedstawicieli linii Starzeńskich z Sobiejuchów i Staroźrebów (Z. Lasocki, Szkice z dziejów szlachty zawkrzeńskiej, „Miesięcznik Heraldyczny” 1931, 10, s. 266-267). W SW pokwitował osobiście. 
Grzegorz Zieliński ${ }^{106}$

\title{
Województwo mazowieckie
}

\author{
Powiat czerski \\ Stanisław Machnicki ${ }^{107}$ \\ Krzysztof Warszewicki $^{108}$ \\ Powiat warszawski \\ Mikołaj Grzybowski $^{109}$ \\ Paweł Zawisza ${ }^{110}$ \\ Powiat wiski \\ Mikołaj Wilga $^{111}$ \\ Wielisław Ławski $^{112}$
}

106 Grzegorz Zieliński h. Świnka (zm. 1599), dworzanin Zygmunta Augusta, sęd. z. płocki 1561-1576, klan płocki 1576-1582, wda płocki 1582-1599 (E. Opaliński, op. cit., s. 76, 293, gdzie sprostowanie błędnej daty objęcia urzędu wdy podanej przez R. Zielińskiego, Wojewoda płocki Grzegorz Zieliński (zm. 1599), „Notatki Płockie” 1957, 6, s. 2-8).

107 Stanisław Machnicki h. Rogala, sęd. z. czerski (od ok. 1582; Bon., t. 16, s. 208; Nies., t. 6, s. 301; Uruski, t. 10, s. 84-65). W SW pokwitował osobiście.

${ }^{108}$ Krzysztof (a nie jak w SK: Jan) Warszewicki, syn Jana klana warszawskiego (zm. $1557)$ h. Paprzyca (1543 - 10/11 IX 1603), pisarz polityczny i mówca (T. Wierzbowski, Krzysztof Warszewicki 1543-1603 i jego dzieła. Monografia historyczno-literacka, Warszawa 1887; [hasło] Krzysztof Warszewicki, w: Piśmiennictwo Staropolskie. Hasła osobowe: $N-\dot{Z}$, red. R. Pollak i in., Warszawa 1965 [„Bibliografia Literatury Polskiej - Nowy Korbut”, t. 3], s. 376-380). W SW pokwitował osobiście.

109 Mikołaj Grzybowski h. Prus II (zm. po 1590 a przed kwietniem 1598), pkom. warszawski od 10 czerwca 1567 (Matricularum Regni Poloniae summaria, excussis codicibus, qui in Chartophylacio Maximo Varsoviensi asservantur ps 5, vol. 2, Acta vicecancellariorum 1548-1572 (...), Varsoviae 1961, nr 9944 - za zwrócenie mi uwagi na tę informację dziękuję Edwardowi Opalińskiemu) a nie od 1564 r. jak w PSB, sta mławski, marsz. izby poselskiej na sejmie 1572 r. (E. Opaliński, op. cit., s. 97, 101; R. Żelewski, Grzybowski Mikołaj, PSB, t. 9, s. 110-111). W SW pokwitował osobiście.

110 Paweł Zawisza h. Półkozic, pstol. warszawski (nominacja 13 VII 1563 - AGAD,

Ks. ziemskie błońskie, Seria I inscriptiones, sygn. 10, k. 413; Nies., t. 10, s. 112).

111 Mikołaj Wilga h. Nałęcz, sta ostrołęcki 1565-1580 (K. Chłapowski, op. cit., s. 81; W. Wittyg, Nieznana szlachta polska i jej herby, Kraków 1908, s. 349; Nies., t. 9, s. 337). W SW pokwitował osobiście.

112 Wielisław Ławski h. Dołęga (zm. krótko przed 20 III 1577), pis. z. wiski (Bon., t. 15, s. 238). W SW pokwitował osobiście. 
Powiat wyszogrodzki $\underline{\text { Stanisław Kobylnicki }}^{\text {Jan Cybulski }^{114}}$

Powiat zakroczymski

Jakub Żabicki ${ }^{115}$

Jan Nowodworski ${ }^{116}$

Powiat ciechanowski

Andrzej Krasiński ${ }^{117}$

Stanisław Śmieciński ${ }^{118}$

Powiat łomżyński

Marcin Mężyński ${ }^{119}$

Mikołaj Wierzbicki ${ }^{120}$

113 Stanisław Kobylnicki (Kobyliński) h. Prawdzic, chor. zakroczymski (I. Kaniewska, Kobylnicki Stanisław, PSB, t. 13, s. 173-174). W SW pokwitował osobiście 48 zł.

114 Jan Cybulski h. Prawdzic, sekretarz królewski, sta piątkowski, wojski wyszogrodzki, poborca z. łęczyckiej (Bon., t. 3, s. 236; Nies., t. 3, s. 156; Uruski, t. 2, s. 337-338).

115 Jakub Żabicki h. Prawdzic, 14 października 1574 występuje jako pkom. zakroczymski (BPAU-PANKr, Teki Pawińskiego, t. 36, k. 30; za zwrócenie mi uwagi na tę informację dziękuję Edwardowi Opalińskiemu; PZK, s. 194, 202; Nies., t. 10, s. 6). W SW pokwitował osobiście.

116 Jan (a nie jak w SK: Julian) Nowodworski h. Nałęga (Nies., t. 6, s. 594).

117 Andrzej Krasiński h. Ślepowron (zm. 1588), sęd. z. ciechanowski 1567-1588 (I. Kaniewska, Krasiński Andrzej, PSB, t. 15, Wrocław 1970, s. 169-170). W SW pokwitował osobiście $48 \mathrm{zł}$.

118 Stanisław Śmieciński (Śmieczyński, Śnieczyński) h. Lis (zm. po 1588; W. Wittyg, op. cit., s. 297; Nies., t. 8, s. 419). W SW wpisany dwukrotnie tą samą ręką (wpisy następują bezpośrednio po sobie, z tym, że pierwszy z nich jest rozmazany i niedokończony).

${ }^{119}$ Marcin Mężyński h. Kościesza (zm. ok. 1598) (H. Kowalska, Mężyński Marcin, PSB, t. 20, s. 517-518). Nominowany na psęd. zambrowskiego 29 maja 1564 (Matricularum Regni Poloniae summaria, excussis codicibus, qui in Chartophylacio Maximo Varsoviensi asservantur ps 5: Sigismundi Augusti regis tempora complectens (1548-1572), vol. 1, Acta cancellariorum 1548-1572 (...), Varsoviae 1919, nr 2919), od 1582 kasztelan wiski (L. Kieniewicz, Senat za Stefana Batorego, Warszawa 2000, s. 308 - za zwrócenie mi uwagi na powyższe informacje dziękuję Edwardowi Opalińskiemu). W SW pokwitował osobiście 48 zł.

${ }^{120}$ Mikołaj Wierzbicki h. Ślepowron, pis. z. łomżyński (Nies., t. 9, s. 313; Paprocki, s. 411-412). 
Ziemia nurska ${ }^{121}$

Jakub Gulczewski ${ }^{122}$

Stanisław Górski ${ }^{123}$

Powiat różański

Jan Karniewski ${ }^{124}$

Andrzej Ponikiewski ${ }^{125}$

Powiat liwski

Bartłomiej Zaliwski ${ }^{126}$

Franciszek Górski ${ }^{127}$

\title{
Województwo podlaskie
}

\author{
Powiat drohicki \\ Sebastian Suchodolski ${ }^{128}$ \\ Melchior Nieciecki $^{129}$
}

121 Ziemia nurska składała się z powiatów: nurskiego, kamienieckiego i ostrowskiego.

${ }^{122}$ Jakub (a nie jak w SK: Jarosław) Gulczewski (Golczewski, Galczowski) h. Junosza (zm. ok. 1585); skarbnik nurski, psęd. z. nurski 1576/1577 (Nies., t. 3, s. 329).

${ }^{123}$ Trudno o jednoznaczną identyfikację posła. W grę wchodzą: 1) Stanisław Górski h. Nałęcz (zm. przed 1578; Bon., t. 6, s. 274; Nies., t. 4, s. 213; Uruski, t. 4, s. 282); 2) Stanisław Górski h. Nałęcz (zm. 1607), pis. z. zakroczymski (Bon., t. 6, s. 275; Nies., t. 4, s. 213; VL 2, s. 339).

124 Jan Karniewski (Karniowski) h. Dąbrowa (zm. 1581), 1580-1581 chor. ciechanowski (Bon., t. 9, s. 262; Nies., t. 5, s. 37; Uruski, t. 6, s. 211). W SW pokwitował osobiście $48 \mathrm{zl}$. s. 232).

125 Andrzej Ponikiewski h. Trzaska, sęd. z. różański (Nies., t. 7, s. 381; Uruski, t. 14,

126 Bartłomiej Zaliwski h. Junosza, chor. liwski 1573-1593 (L. Zalewski, Szlachta ziemi liwskiej. Sejmiki, urzędy, herbarz, Warszawa 2005, s. 74, 180; Nies., t. 10, s. 46).

127 Franciszek Górski h. Ślepowron, nominowany na wojskiego liwskiego 5 V 1570 (Matricularum Regni Poloniae summaria, excussis codicibus, qui in Chartophylacio Maximo Varsoviensi asservantur ps 5: Sigismundi Augusti regis tempora complectens (1548-1572), vol. 1 (...), nr 4163 - za zwrócenie mi uwagi na powyższą informację dziękuję Edwardowi Opalińskiemu; L. Zalewski, op. cit., s. 80, 117; Bon., t. 6, s. 287, Uruski, t. 4, s. 288).

128 Sebastian Suchodolski h. Pobóg, wojski drohicki 1576-1584, referendarz litewski 1569-1579 (Urzędnicy, t. 11, s. 242; Urzędnicy, t. 8, s. 98). W SW pokwitował osobiście 48 zł.

129 Melchior Nieciecki h. Poraj, pkom. drohicki 1566-1583 (Urzędnicy, t. 8, nr 484). W SW wpisany dwukrotnie tą samą ręką (pierwszy wpis: „Malcher Nyeczyczki succamerarius Drohicensis” [k. 282] przekreślony, drugi: „Malcher Nyeczyczki” [k. 282v]). 
Powiat bielski

Stanisław Grajewski ${ }^{130}$

Andrzej Jałbrzyk Wyszyński ${ }^{131}$

Powiat mielnicki

Maciej Sawicki ${ }^{132}$

Niemiera podstoli podlaski ${ }^{133}$

\section{Województwo rawskie}

Ziemia rawska

Jan Plichta ${ }^{134}$

Stanisław Chociwski ${ }^{135}$

Ziemia sochaczewska

Marcin Szymanowski ${ }^{136}$

Wawrzyniec Gradows $\mathrm{ki}^{137}$

Ziemia gostyńska

Stanisław Grzywa ${ }^{138}$

130 Stanisław Grajewski h. Gozdawa (zm. przed 4 IX 1600), dworzanin królewski, psta. włodzimierski 1575, stol. podlaski 1575-1585 (Urzędnicy, t. 8, nr 1354). W SW pokwitował osobiście $48 \mathrm{zł}$. Wpis został przekreślony.

131 Andrzej Jałbrzyk Wyszyński h. Grab, pis. gr. brański 1573-1590, wojski drohicki 1586-1591, psta. gr. brański 1590-1591, sęd. bielski 1591 - zm. przed 23 lutego 1595 (Urzędnicy, t. 8, s. 197). W SW pokwitował osobiście $48 \mathrm{zł.}$

132 Maciej (Matys) Sawicki h. Lubicz (zm. 1581), pis. litewski 1566-1581, wojski drohicki 1569-1570, sta mielnicki 1567 - 16 IV 1574, sta łosicki 1569, klan podlaski 1574-1581 (I. Kaniewska, Sawicki Maciej, PSB, t. 35, Warszawa-Kraków 1994, s. 334-336; Urzędnicy, t. 8, s. 190; Urzędnicy, t. 11, s. 239). W SW pokwitował osobiście 48 zł.

133 Brak podanego w SK imienia posła utrudnia jego identyfikację. Mógł być to zarówno Stanisław Niemiera wzm. z pstol. podlaskim w 1577 r. (Urzędnicy, t. 8, s. 181) jak i Jan Niemiera, pstol. podlaski (1 IX 1576 - 1594; Urzędnicy, t. 8, s. ut supra).

134 Jan Plichta h. Półkozic, poborca rawski (zm. 1577; Nies., t. 7, s. 326; Uruski, t. 14, s. 79). W SK jako podczaszy rawski.

135 Stanisław Chociwski z Chociwia h. Dąbrowa, sęd. z. rawski (Uruski, t. 2, s. 263). W SW pokwitował osobiście $30 \mathrm{zł}$.

${ }_{136}$ Marcin Szymanowski z Szymanowa h. Ślepowron (Nies., t. 8, s. 644). W SW pokwitował osobiście $30 \mathrm{zł}$.

137 Wawrzyniec Gradowski z Gradowa h. Lubicz (zm. 1593), cz., sęd. i chor. sochaczewski (Bon., t. 7, s. 34; Nies., t. 4, s. 272; Uruski, t. 4, s. 358).

138 Stanisław Grzywa h. Kościesza (zm. przed 1576; Bon., t. 7, s. 182). 
Jan Trąmbski ${ }^{139}$

\title{
Województwo bracławskie
}

\author{
Powiat bracławski \\ Mikołaj Szaszkiewicz Dołbunowski ${ }^{140}$ \\ Bogusz Deszkowski ${ }^{141}$
}

Powiat winnicki
\[ \begin{array}{l}\text { Andrzej Sadowski }{ }^{142} \\ \text { Bernard Jaruszowski }\end{array}{ }^{143} \]

\section{Streszczenie}

Obradujący w Krakowie w dniach od 21 lutego do 22 kwietnia 1574 r. sejm koronacyjny był jedynym, który odbył się podczas krótkiego panowania Henryka Walezego, pierwszego wybranego w wolnej elekcji króla Polski. Dotychczas na podstawie nielicznych wzmianek ustalono nazwiska 43 członków izby poselskiej. Podstawą do sporządzenia niniejszej listy parlamentarzystów są dwa, dotychczas niewykorzystane przez badaczy, źródła. Pierwszy z nich to spis posłów przygotowany najprawdopodobniej na polecenie marszałka izby poselskiej: „Nuncii terrestres Regni Poloniae in Conventu Coronationis Anno 1574" (Kraków, Biblioteka Czartoryskich, Zbiory Muzeum Narodowego w Krakowie, sygn. 522/2). Spisano go na potrzeby podskarbiego nadwornego, który na jego podstawie dokonywał wypłaty należnego posłom zryczałtowanego wynagrodzenia za uczestnictwo w pracach parlamentu (tzw. pieniądze strawne). W spisie wymieniono 113 posłów, zgodnie z formularzem znanym ze spisów strawnego, a więc podzielonych według województw i ziem oraz powiatów, z których zostali wybrani. Uzupełniający charakter ma drugie źródło: "Expeditio nuntiorum terrestrium in Conventione quails felicis Coronationis SMR" (Warszawa, Archiwum Główne Akt Dawnych, Archiwum Skarbu Koronnego, oddz. I, Rachunki królewskie, sygn. 361, k. 276-282v). Na kolejnych kartach wpisano po łacinie nazwy województw, pozostawiając jednocześnie między kolejnymi wpisami wolne miejsce. Tak przygotowany formularz został wykorzystany do kwitowania

139 Jan Trąmbski (Trambski) h. Prawdzic (Nies., t. 9, s. 109).

140 Mikołaj Szaszkiewicz Dołbunowski h. własnego, pkom. bracławski (Nies., t. 8, s. 604; K. Mazur, op. cit., s. 210; H. Litwin, Rody pańskie, s. 278). W SW pokwitował osobiście $48 \mathrm{zł}$.

141 Bogusz Deszkowski h. Chorągwie, chor. bracławski (Bon., t. 4, s. 268; Nies., t. 3, s. 339; Uruski, t. 3, s. 159; K. Mazur, op. cit., s. 49; H. Litwin, Rody pańskie, s. 277).

${ }^{142}$ Andrzej Sadowski h. Lubicz, psęd. bacławski (Nies., t. 8, s. 228; K. Mazur, op. cit., s. 423). W SW pokwitował osobiście $48 \mathrm{zł}$.

${ }^{143}$ Niezidentyfikowany. W SK: „Bernardus Jarushowski”. 
przez posłów odbioru pieniędzy strawnych. Odbierali oni gotówkę osobiście lub czynili to w ich imieniu słudzy lub inni posłowie. W ten sposób odbiór strawnego pokwitowało 79 posłów na sejm koronacyjny. Wszystkie nazwiska pokrywają się z pierwszym rejestrem.

\section{Register of Crown envoys to the 1574 Coronation Sejm}

Held in Kraków between 21 February and 22 April 1574 the Coronation Sejm was the only Sejm to convene during a short reign of King Henry Valois - the first king of Poland elected by free election. Until now, on the basis of scarce historical sources, the names of forty-three members of the Chamber of Envoys have been established. The present list of envoys is made on the basis of two sources, so far not studied by researchers. The first of them is a register of envoys, most probably written on the order of the marshal of the Chamber of Envoys (Nuncii terrestres Regni Poloniae in Conventu Coronationis Anno 1574: Kraków, the Princes Czartoryski Library, National Museum in Kraków, MS 522/2). It was compiled for the court treasurer who according to this list paid out a flat-rate fee to the envoys who participated in parliamentary activities (the so-called strawne money). The list includes 113 names, on the basis of a form known from the strawne registers, that is divided according to palatinates, lands and districts, from which they were elected. The list is supplemented by the second source: Expeditio nuntiorum terrestrium in Conventione quails felicis Coronationis SMR (Warsaw, the Central Archives of Historical Records, Archives of the Crown Treasury, dep. I: Royal Bills, MS 361, fols. 276-282v). In the following pages the names of palatinates in Latin are written, with some space between the entries. The form was used for the envoys to sign the reception of money, which was taken personally by them or by their servants or other envoys on their behalf. The reception was confirmed by 79 envoys of the Coronation Sejm. All the names are in the first register.

Translated by Grażyna Waluga

\section{Bibliografia}

Bodniak Stanisław, Drohojowski Stanisław, PSB, t. 5, Kraków 1939-1946, s. 388.

Boniecki Adam, Herbarz polski, Gebethner i Wolff, Warszawa 1899-1913.

Budka Włodzimierz, Dembiński Stanisław, PSB, t. 5, Kraków 1939-1946, s. 74-75.

Budka Włodzimierz, Kmita Jan, PSB, t. 13, Wrocław 1967-1968, s. 92.

Byliński Jan, Przerębski Stanisław, PSB, t. 29, Kraków 1986, s. 1-2.

Chłapowski Krzysztof, Starostowie w Wielkopolsce, na Kujawach i Mazowszu 1565-1696. Materiały źródłowe, IH PAN, Warszawa 2007.

Chynczewska-Hennel Teresa, Ostrogski Konstanty Wasyl, PSB, t. 24, Wrocław 1979, s. 495.

Czarnecki Włodzimierz, Szlachta ziemi chełmskiej do połowy XVI wieku, Instytut Badań nad Dziedzictwem Kulturowym Europy, Białystok 2012. 
Czarnecki Włodzimierz, Uhrowieccy h. Suchekomnaty $w$ ziemi chełmskiej do połowy XVI wieku do połowy XVI wieku, „Wschodni Rocznik Humanistyczny” 6, 2009, s. 7-24.

Dembińska Anna, Czarnkowski Wojciech Sędziwój, PSB, t. 4, Kraków 1938, s. 225-226. Dembińska Anna, Czerski Walenty, PSB, t. 4, Kraków 1938, s. 348.

Dubas-Urwanowicz Ewa, Koronne zjazdy szlacheckie w dwóch pierwszych bezkrólewiach po śmierci Zygmunta Augusta, Wydawnictwo Uniwersytetu w Białymstoku, Białystok 1998.

Dworzaczek Włodzimierz, Kowalska Halina, Przyjemski Stanisław, PSB, t. 29, Wrocław 1986, s. 181-185.

Dworzaczek Włodzimierz, Ostroróg Lwowski Marcin, PSB, t. 24, Wrocław 1979, s. 513-514.

Dzięgielewski Jan, Olizar Adam, PSB, t. 23, Wrocław 1978, s. 805.

Ferenc Marek, Rejestr wypłat strawnego dla posłów ziemskich koronnych na sejm warszawski 1582 r., SH 51, 2008, 1, s. 91-104.

Filipczak-Kocur Alicja, Kto wypłacał diety poselskie w XVII wieku?, w: Parlament, prawo, ludzie. Studia ofiarowane profesorowi Juliuszowi Bardachowi w sześćdziesięciolecie pracy twórczej, red. Katarzyna Iwanicka, Maria Skowronek, Kazimierz Stembrowicz, Wydawnictwo Sejmowe, Warszawa 1996, s. 68-73.

Grzybowski Stanisław, Henryk Walezy, Ossolineum, Wrocław 1985.

Halecki Oskar, Bokiej Gabriel, PSB, t. 2, Kraków 1936, s. 243-244.

Kamieński Andrzej, Sierakowski Stanisław, PSB, t. 37, Warszawa-Kraków 1996, s. 299-302.

Kaniewska Irena, „Strawne pieniądze” posłów koronnych w XVI wieku, w: Poprzez stulecia. Księga pamiatkowa ofiarowana profesorowi Antoniemu Podrazie w 80. rocznice Jego urodzin, red. Danuta Czerska, Historia Iagellonica, Kraków 2000, s. 57-66.

Kaniewska Irena, Kobylnicki Stanisław, PSB, t. 13, Wrocław 1967-1968, s. 173-174.

Kaniewska Irena, Koniecpolski Mikołaj, PSB, t. 13, Wrocław 1967-1968, s. 522.

Kaniewska Irena, Krasiński Andrzej, PSB, t. 15, Wrocław 1970, s. 169-170.

Kaniewska Irena, Latalski Janusz, PSB, t. 16, Wrocław 1971, s. 564.

Kaniewska Irena, Łaszcz Aleksander, PSB, t. 18, Wrocław 1973, s. 259-260.

Kaniewska Irena, Przyłęcki Marian, PSB, t. 29, Wrocław 1986, s. 197-199.

Kaniewska Irena, Sawicki Maciej, PSB, t. 35, Warszawa-Kraków 1994, s. 334-336.

Kaniewska Irena, Skotnicki Paweł, PSB, t. 38, Warszawa-Kraków 1997-1998, s. 306-307.

Kaniewska Irena, Strasz Leonard, PSB, t. 44, Warszawa-Kraków 2006-2007, s. 206-208.

Kempa Tomasz, Dzieje rodu Ostrogskich, Adam Marszałek, Toruń 2002.

Kieniewicz Leszek, Senat za Stefana Batorego, Wydawnictwo Sejmowe, Warszawa 2000.

Konopczyński Władysław, Chronologia sejmów polskich 1493-1793, Akademia Umiejętności, Kraków 1948.

Kotarski Henryk, Lanckoroński Stanisław, PSB, t. 16, Wrocław 1971, s. 452-453.

Kowalska Halina, Gołuchowski Andrzej, PSB, t. 8, Kraków 1959-1960, s. 261-262.

Kowalska Halina, Małachowski Mikołaj, PSB, t. 19, Wrocław 1974, s. 408.

Kowalska Halina, Mężyński Marcin, PSB, t. 20, Wrocław 1975, s. 517-518.

Kowalska Halina, Młodziejowski Jacek, PSB, t. 21, Wrocław 1976, s. 433-434. 
Kowalska Halina, Rokossowski Jakub, PSB, t. 31, Wrocław 1988, s. 537.

Kowalska Halina, Stanisław Szafraniec z Pieskowej Skały, OiRP 3, 1958, s. 99-131.

Krzysztof Warszewicki [hasło], w: Piśmiennictwo Staropolskie. Hasła osobowe: $\mathrm{N}-\dot{Z}$, red. Roman Pollak i in., PIW, Warszawa 1965 [„Bibliografia Literatury Polskiej Nowy Korbut", t. 3], s. 376-380.

Kupisz Dariusz, Gorajscy w XV-XVI wieku. Studium z dziejów awansu społeczno-politycznego rodziny szlacheckiej, „Almanach Historyczny” 3, 2001, s. 29-31.

Lasocki Zygmunt, Szkice z dziejów szlachty zawkrzeńskiej, „Miesięcznik Heraldyczny” 10, 1931, s. 241-250, 265-268.

Leitgeber Sławomir, Potulicki Piotr, PSB, t. 28, Wrocław 1984-1985, s. 252-255.

Lepszy Kazimierz, Czarnkowski Stanisław Sędziwój, PSB, t. 4, Kraków 1938, s. 221-224. Lepszy Kazimierz, Drohojowski Jan Tomasz, PSB, t. 5, Kraków 1939-1946, s. 382-385. Lepszy Kazimierz, Firlej Andrzej, PSB, t. 6, Kraków 1948, s. 474-475.

Lepszy Kazimierz, Gostomski Hieronim, PSB, t. 8, Wrocław 1959-1960, s. 364-366. Lepszy Kazimierz, Górka Stanisław, PSB, t. 8, Wrocław 1959-1960, s. 416-424. Lepszy Kazimierz, Grudziński Stefan, PSB, t. 9, Wrocław 1960-1961, s. 47-48. Lipski Andrzej, Ponętowski Walenty, PSB, t. 27, Wrocław 1982-1983, s. 405-406. Litwin Henryk, Rody pańskie Kijowszczyzny 1569-1648. Status majątkowy, „Przegląd Wschodni" 8, 2002, 2 (30), s. 235-292.

Litwin Henryk, Równi do równych. Kijowska reprezentacja sejmowa 1569-1648, DiG, Warszawa 2009.

Lubczyński Mariusz, Wykazy posłów sejmowych z lat 1507-1512, KH 122, 2015, 3, s. 509-537.

Makiłła Dariusz, Zabójstwo Andrzeja Wapowskiego, kasztelana przemyskiego, przez Samuela Zborowskiego na sejmie koronacyjnym króla Henryka Walezego w 1574 r. Z zasad stosowania spraw postepk ku sadowego w sprawach karnych w dawnej Polsce, w: Historia testis temporum, lux veritatis, vita memoriae, nuntia vetustatis. Księga Jubileuszowa dedykowana Profesorowi Włodzimierzowi Kaczorowskiemu, red. Ewa Kozierska, Marek Maciejewski, Piotr Stec, Wydawnictwo Uniwersytetu Opolskiego, Opole 2015, s. 237-253.

Matricularum Regni Poloniae summaria, excussis codicibus, qui in Chartophylacio Maximo Varsoviensi asservantur ps 5: Sigismundi Augusti regis tempora complectens (15481572), vol. 1, Acta cancellariorum 1548-1572, contexuit indicesque adiecit Theodorus Wierzbowski, Varsoviae 1919.

Matricularum Regni Poloniae summaria, excussis codicibus, qui in Chartophylacio Maximo Varsoviensi asservantur ps 5: Sigismundi Augusti regis tempora complectens (15481572), vol. 2, Acta vicecancellariorum 1548-1572, contexuerunt Josephus Płocha, Antonius Rybarski, Irena Sułkowska; moderante Jacobo Sawicki; Directio Generalis Archivorum Status. Tabularium Actorum Antiquorum Varsoviense Maximum, Varsoviae 1961.

Mazur Karol, W stronę integracji z Korona. Sejmiki Wołynia i Ukrainy w latach 1569-1648, Neriton, Warszawa 2006.

Niesiecki Kacper, Herbarz polski, wyd. Jan Nepomucen Bobrowicz, Breitkopf i Hærtel, Lipsk 1839-1846.

Opaliński Edward, Rodziny wielkosenatorskie w Wielkopolsce, na Kujawach i na Mazowszu za Zygmunta III. Podstawy karier, DiG, Warszawa 2007. 
Paprocki Bartosz, Herby rycerstwa polskiego na pięcioro ksiag rozdzielone, wyd. Kazimierz Józef Turowski, Wydawnictwo Biblioteki Polskiej, Kraków 1858.

Piekosiński Franciszek, Księga podskarbińska nr 8 z lat 1571-1575, w: Wypisy heraldyczne z ksiag poborowych, „Rocznik Towarzystwa Heraldycznego” 2, 1910.

Pielas Jacek, Działalność Oleśnickich jako przedstawicieli sejmiku województwa sandomierskiego w XVI-XVII w., „Między Wisłą a Pilicą. Studia i materiały historyczne” 1, 2000, s. 119-132.

Pielas Jacek, Oleśniccy herbu Dębno w XVI-XVII wieku. Studium z dziejów zamożnej szlachty doby nowożytnej, Wydawnictwo Akademii Świętokrzyskiej, Kielce 2007.

Plewczynski Marek, Sieniawski Mikołaj, PSB, t. 37, Warszawa-Kraków 1998-1997, s. 125.

Płokarz Józefat, Jan Niemojewski. Studium z dziejów arian w Polsce, „Reformacja w Polsce" 2, 1922, s. 71-75.

Posłowie ziemscy koronni 1493-1600, red. Irena Kaniewska, Wydawnictwo Sejmowe, Warszawa 2013.

Przyboś Kazimierz, Reprezentacja sejmowa ziemi przemyskiej w latach 1573-1695, „Rocznik Przemyski” 34, 1998, 1, s. 3-36.

Rachuba Andrzej, Litewscy marszałkowie sejmów Rzeczypospolitej (1569-1793), w: Kultura parlamentarna epoki staropolskiej. Studia, red. Andrzej Stroynowski, DiG, Warszawa 2013, s. 33-46.

Ramadan Andrej, Ferenc Marek, Rejestr senatorów i posłów na sejmie walnym warszawskim 9 lutego - 21 marca 1600 r., „Zeszyty Naukowe Uniwersytetu Jagiellońskiego” 767, Prace Historyczne 131, 2004, s. 89-107.

Rosin Ryszard, Masłowski Gabriel, PSB, t. 20, Wrocław 1975, s. 127.

Seredyka Jan, Parlamentarzyści polscy od końca XV wieku do 1632 r., w: Parlamentarzyści polscy od XVI do XX wieku. Stan badań i postulaty, red. J. Seredyka, Wydawnictwo Uniwersytetu Opolskiego, Opole 1999, s. 7-14.

Serwański Marek, Henryk Walezy w Polsce. Stosunki polsko-francuskie w latach 1566-1576, Wydawnictwo Literackie, Kraków 1976.

Tazbir Janusz, Niemojewski Jakub, PSB, t. 23, Wrocław 1978, s. 10-13.

Ternes Jerzy, Przyczynki do genealogii Żółkiewskich w XVI w., „Rocznik Lubelskiego

Towarzystwa Genealogicznego" 4, 2012, s. 84-95.

Topolska Maria B., Ostroróg Jan, PSB, t. 24, Wrocław 1979, s. 505-506.

Tyszkowski Kazimierz, Agryppa Wacław, PSB, t. 1, Kraków 1935, s. 32-33.

Uruski Seweryn, Kosiński Adam, Włodawski Aleksander, Rodzina. Herbarz szlachty polskiej, Gebethner i Wolff, Warszawa 1904-1938.

Uruszczak Wacław, Sejm walny koronny w latach 1506-1540, PWN, Warszawa 1980.

Urwanowicz Jerzy, Od towarzysza obrony potocznej do kasztelana halickiego. Pierwszy etap kariery Stanisława Żółkiewskiego (1520-1580), w: Historia testis temporum, lux veritatis, vita memoriae, nuntia vetustatis. Ksiegga Jubileuszowa dedykowana Profesorowi Włodzimierzowi Kaczorowskiemu, red. Ewa Kozierska, Marek Maciejewski, Piotr Stec, Wydawnictwo Uniwersytetu Opolskiego, Opole 2015, s. 183-198.

Wierzbowski Teodor, Krzysztof Warszewicki 1543-1603 i jego dzieła. Monografia historyczno-literacka, E. Wende i Sp., Warszawa 1887.

Wittyg Wiktor, Nieznana szlachta polska i jej herby, Drukarnia UJ, Kraków 1908. 
Zalewski Leszek, Szlachta ziemi liwskiej. Sejmiki, urzędy, herbarz, Paleta-Art — R. Paszkowski, Warszawa 2005.

Zieliński Ryszard, Wojewoda płocki Grzegorz Zieliński (zm. 1599), „Notatki Płockie” 1957, 6, s. 2-8.

Żelewski Roman, Grzybowski Mikołaj, PSB, t. 9, Wrocław 1960-1961, s. 110-111.

Żelewski Roman, Herburt Mikołaj, PSB, t. 9, Wrocław 1960-1961, s. 449-450.

Biogram: dr Rafał Jaworski, adiunkt, Instytut Historii i Stosunków Międzynarodowych, Uniwersytet Jana Kochanowskiego w Kielcach, Filia w Piotrkowie Trybunalskim; zainteresowania badawcze: historia państwa Jagiellonów, nauki pomocnicze historii (edytorstwo, sfragistyka), archiwistyka (archiwoznawstwo); kontakt: r.a.jaworski@wp.pl. 